\title{
中耳・耳管・咽頭の自律神経支配に関する研究
}

\author{
大八木 章 博
}

\section{A Study of the Autonomic Innervations in the Middle Ear, Eustachian Tube and Pharynx}

\author{
Shohaku Oyagi \\ (Tenri Hospital)
}

Autonomic innervations of the mucosa in the middle ear, Eustachian tube and pharynx were investigated by retrograde labelling of the autonomic ganglia with horseradish peroxidase (HRP). Of the sympathetic ganglia, the superior cervical ganglion (SCG), middle cervical ganglion (MCG) and stellate ganglion ( $\mathrm{StG}$ ) were examined, and of the parasympathetic ganglia, the pterygopalatine ganglion ( $\mathrm{PpG}$ ) and the otic ganglion (OtG) were examined.

1. The sympathetic innervation of the middle ear mucosa was by fibers originating in the ipsilateral SCG, but not by those originating in the MCG or StG. The parasympathetic innervation was by fibers originating in the ipsilateral $\mathrm{PpG}$, but not by those originating in the $\mathrm{OtG}$.

2. The sympathetic innervation of the Eustachian tube mucosa was by fibers originating in the ipsilateral SCG and MCG, but not by those from the StG; parasympathetic innervation was by fibers originating in the ipsilateral $\mathrm{PpG}$, but not by those from the OtG.

3. The epipharynx received sympathetic innervation from the ipsilateral SCG, but not from the MCG or StG. Its parasympathetic innervation was from the PpGs bilaterally, but not from the OtG.

4. The sympathetic innervation of the mesopharynx was from the SGG, MGG and $\mathrm{StG}$, but the parasympathetic supply was from neither the PpG nor the OtG. Sympathetic innervation was bilateral, but predominantly from the ipsilateral side.

5. The hypopharynx resembled the mesopharynx, but had more innervation from the MCG and StG.

Key words: middle ear, Eustachian tube, pharynx, autonomic innervation, horseradish peroxidase (HRP)

緒言

自律神経系は各種臟器の平滑筋や分泌腺など， 直接生命維持に必要な作用を調節する反射的な 神経系統であり，耳鼻咽喉科領域においても各 器官で自律神経支配の存在が確かめられている.
即ち中耳に関しては，1950年頸動脈神経叢か らの交感神経線維が鼓室に分布しているととが 報告され(1)，以後主に組織化学的手法により自 律神経線維の存在が確かめられてきた ${ }^{22}$ ５)。 こ れらの自律神経は中耳粘膜の血流や分泌腺活動, 
線毛機能に影響を及ぼすむのと考えられている。

耳管の自律神経支配については，1963年血 管収縮剂が耳管腔を開大させることが報告さ れ6)，以後種々の自律神経作働薬によっても耳 管の開放度が変化することが確かめられてい $3^{778)}$. また中耳粘膜におけると同様, 組織化 学的な手法により自律神経線維が分布している ことも確办められている年 111.

咽頭の自律神経は舌咽, 迷走神経および上頸 神経節からの咽頭枝が吻合して作られる咽頭神

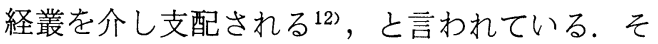
して咽頭の処置でしばしば惹き起てされるショ ック症状は, 自律神経分布が密であるため咽頭 の被刺激性が高いととに起因すると推測されて いる ${ }^{13)}$.

このような解剖学的，生理学的研究あるいは 臨床的観察により中耳, 耳管, 咽頭に対する自 律神経支配の実態は明らかにされてきたが，自 律神経の支配様式や各器官に分布している節後 線維の起源, あるいは各器官の機能に及ぼす自 律神経の影響などについては未だなお不明な点 あ残されている。

一方, 過酸化酵素 horseradish peroxidase (HRP) を神経組織内に取り込ませ標識すると とにより，神経系の線維連絡を追跡研究する 方法が1971年 Kristensson らによって報告され

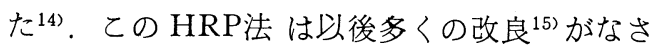
れ，今日では形態学のみならず生理学領域でも 簡易かつ鋭敏な研究方法として広く用いられて おり ${ }^{16)}$ ，耳鼻咽喉科領域においても HRP 法に よる研究が既に幾つか報告されている(17) 19).

本研究では HRP が自律神経の節後線維終末 から取り込まれ，軸索を逆行性に輸送されて自 律神経節を標識し得ることを利用し，中耳，耳 管，咽頭の自律神経支配につき検討するととを 目的とした．本法によればどの自律神経節から の支配を受けているかだけではなく，神経節内 の HRP 標識細胞数を観察することにより, 各 神経節からの支配の量的評価もできると考えた．

\section{実験方法}

実験にはネコ（体重 2.5〜 5.1 kg）30匹を用 いた。 そのうち中耳に HRP を投与した例が 8 匹，耳管に投与したのが10匹，咽頭は上咽頭， 中咽頭，下咽頭に分け投与し各々 4 匹であった。 実験操作はペントバルビタール $(30 \mathrm{mg} / \mathrm{kg})$ を 腹腔内に，1\%リドカインを局所に投与し，十 分な麻酔効果を得た上で行った。

HRP の各器官への投与方法は以下の通りで ある。また HRP の投与部位は全例とも一側の みとした。

1. 中耳への HRP 投与法 (cat no. 1 8) 側頸部皮膚に縦切開を加え腹側より中耳骨胞 を露出，開放し，顕微鏡を用いて岬角を明視下 に㧍いた. 33\% HRP (Toyobo, Grade I -C) 溶 液 $5 \mu \mathrm{l}$ を, Hamilton マイクロシリンジで岬角 粘膜に $2 \sim 3$ 箇所に分け注入した。注射針の刺 入点から HRP 溶液の漏洩がみられた時には, 綿花や吸引管を用いて除去した。 これらの注入 操作に際しては，岬角上に認められる鼓室神経 叢を損傷しないよう注意した. HRP 注入後中 耳腔には抗生剂軟高を含ませた綿花を軽く詰め, 頸部皮虐創を縫合閉鎖した。

2. 耳管への HRP 投与法 (cat no. 9 18) HRP を耳管に投与する場合二通りの投与法 を試みた。、いずれもまず軟口蓋に正中切開を加 え，その切開空より顕微鏡を用い耳管咽頭孔を 明視下においた，第 1 の方法は，HRP 溶液約 $10 \mu \mathrm{l}$ を含む小綿花を耳管腔内に留置する方法 で，乙の際耳管粘膜を損傷しないようにした (cat no. 9〜11). また HRP 溶液が耳管外に洩れ ないよう，耳管の鼓室側と咽頭側とをそれぞれ 骨蠟を含む綿球で閉鎖した．第 2 の方法は，耳 管後壁の粘膜に HRP 溶液約 $15 \mu \mathrm{l}$ をマイクロ シリンジで注入する方法である (cat no. 12〜 18). $2 \sim 3$ 䇢所に分け注入したが，注射針の刺 入点から HRP 溶液の漏洩が認められた時には 吸引管や綿花で除去した. HRP 投与後軟口蓋 の切開創は縫合した。 
3. 咽頭への HRP 投与法 (cat no. 19 30) 咽頭は上, 中, 下咽頭の三領域に分け HRP 溶液を注入した。即ち上咽頭は耳管咽頭孔上方 の側壁 (cat no. 19〜22), 中咽頭は後口蓋弓中間 部後方の側壁 (cat no. 23〜26), 下咽頭は梨状陥 凹外側壁 (cat no. 27〜30) の粘膜に注入した. 上咽頭への注入例では耳管の例之同様, 軟口蓋 に正中切開を加えその切開空より注入した．中 咽頭や下咽頭例では単に開口させるだけで顕微 鏡下に注入した。 HRP 溶液の注入量は各部位

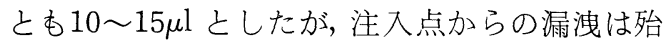
ど認められなかった。 粘膜に注入された HRP 溶液の浸潤範囲は顕微鏡下に黒く認められ，そ れぞれの部位で正中線を越えておらず，また上， 中, 下咽頭の各領域も越えていないことを確認 した.

\section{4. 灌流固定}

$\mathrm{HRP}$ 投与後ネコは $2 \sim 3$ 日生存させ，十分 な麻酔下に灌流固定した。左心室からまずへ パリン 1000 単位を含む約 $37^{\circ} \mathrm{C}$ の生理的食塩水 $1000 \mathrm{ml}$ を流し，次に冷却した $2000 \mathrm{ml}$ の $7 \%$ ホルマリンー0.1 M リン酸緩衝液 $(\mathrm{pH}$ 7.4) で 固定し, その後さらに10\%蔗糖一, $30 \%$ 蔗糖一 0.1 M リン酸緩衝液各 $1000 \mathrm{ml}$ を流した。

灌流固定後直ちに雨側の上頸神経節 superior cervical ganglion, 中頸神経節 middle cervical ganglion, 星状神経節 stellate ganglion, 翼口蓋 神経節 pterygopalatine ganglion および耳神経 節 otic ganglion を摘出した. 交感神経節は頸 部から胸部を切開し摘出したが，中頸神経節は 上頸神経節や星状神経節に較べて小さく，また 存在部位む一定せず確認するのが困難な例もあ った，翼口蓋神経節や耳神経節は開頭後, 頭蓋 底よりそれぞれ三叉神経の第 2 枝, 第 3 枝を顕 微鏡下に追跡し摘出したが同定困難な例ああっ た。

\section{5. 切片作製}

摘出した神経節は $30 \%$ 蔗糖一 $0.1 \mathrm{M}$ リン酸 緩衝液に浸漬し， $4^{\circ} \mathrm{C}$ の冷所に数日間保存した 後, 厚さ $100 \mu \mathrm{m}$ の長軸方向の凍結切片を作製
した. 各切片はテトラメチルベンチジン (tetramethyl benzidine) で呈色反応させ ${ }^{15)}$, 中性赤 (pH 4.8) で染色し，顕微鏡下に HRP 標識細 胞の有無およびその数を検索した.

本研究ではある神経節から作製した全ての切 片につきその標識細胞数を数え，その中で最む 多いものをその神経節の標識細胞数とみなした. 表 1〜 3 の「十」,「H」,「世」は各神経節の標 識細胞数がそれぞれ 1 10，11〜 100，101 以上 であったととを示し，「一」は標識細胞が全く 認められなかったととを示す。

\section{実験結果}

\section{1. 中耳の結果}

中耳に HRP を投与した 8 例の結果を表 1 に まとめた．HRP 注入側と反対側の神経節には 全く HRP 標識細胞を認めなかったので，注入 側の結果のみを示した。即ち8 例全例で HRP 注入側の上頸神経節に HRP 標識細胞を認め た。図 1 のように，上頸神経節の標識細胞は円 形ないしは卵円形で直径は 30〜50 $\mu \mathrm{m}$ であり， 各上頸神経節に認められた標識細胞数は 3 〜 318 個であった。 また摘出し得た 3 例の中頸神 経節之 6 例の星状神経節にはいずれも標識細胞 が認められなかったが，5例の翼口蓋神経節の うち 4 例に標識細胞を認めた。 図 2 は標識され た翼口蓋神経節である，標識細胞は上頸神経節 の標識細胞と類似しているが，上頸神経節の細 胞に較べるとやや小型であった，標識細胞数は 2〜8個であった．検索した 2 例の耳神経節には いずれも標識細胞を認めなかった.

\section{2. 耳管の結果}

HRP を耳管に投与した10例の結果を表 2 に 示す。耳管の場合も中耳と同じく反対側には標 識細胞を認めず，注入側だけの結果を示した。

HRP 溶液を含む綿球の耳管留置例 (cat no. 9〜11)では，いずれの神経節にも標識細胞を認 めなかった。 しかし耳管粘膜への HRP 注入例 (cat no. 12〜18)では，全例で同側の上頸神経節 に標識細胞を認めた。各上頸神経節に認められ た標識細胞数は $2 \sim 485$ 個 で 中耳の場合とほぼ 
表1 中耳の結果

\begin{tabular}{|c|c|c|c|c|c|}
\hline cat no. & $S C G$ & $\mathrm{MCG}$ & $S t G$ & $P p G$ & $O t G$ \\
\hline 1 & 世 & & & + & \\
\hline 2 & 世 & & - & + & \\
\hline 3 & + & - & & & \\
\hline 4 & W & & - & - & \\
\hline 5 & H & - & - & & \\
\hline 6 & $H$ & & - & + & \\
\hline 7 & $H$ & - & - & + & - \\
\hline 8 & H & & - & & \\
\hline
\end{tabular}

SCG：上頸神経節

MCG：中頸神経節

$\mathrm{StG}$ ：星状神経節

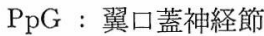

$\mathrm{OtG}$ : 耳神経節

斜線は神経節を検索し得なかったととを示す。
H：101以上

H: $11 \sim 100$

$+: 1 \sim 10$

$-: 0$

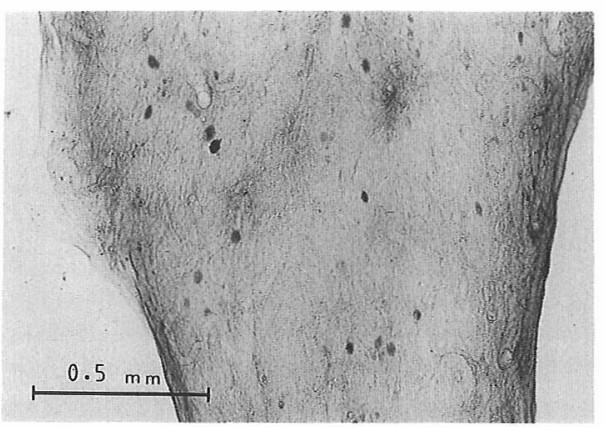

A

図 1 上頸神経節の HRP 標識細胞

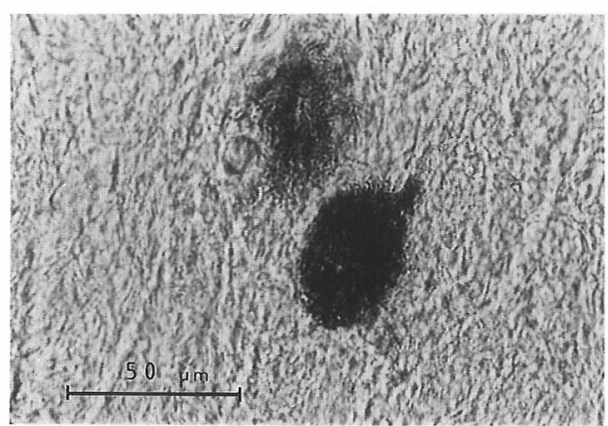

B

(BはAの拡大像)

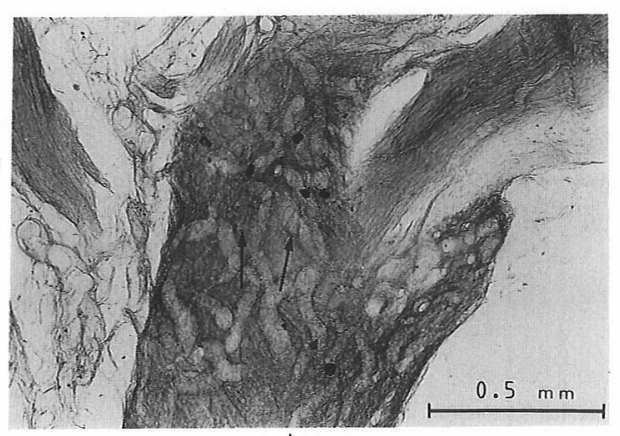

A

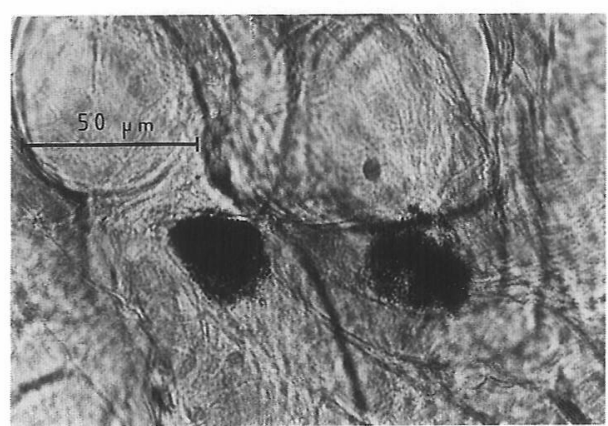

B

図 2 翼口蓋神経節の HRP 標識細胞

(B はAの拡大像) 
同様であった。 またうち1例 (cat no. 13)では同 側の中頸神経節にも標識細胞を認めた。 中頸神 経節の標識細胞は図 3 のように，上頸神経節や 翼口蓋神経節の細胞と較べると小さく紡錘形に 近いものであった，標識細胞数は 3 個であった. 星状神経節には全例標識細胞を認めなかった。

翼口蓋神経節は 7 例中 4 例に標識細胞を認めた. 細胞の形態は中耳の例之同様であり，数は 2 〜 18個であった，耳神経節は検索した 6 例全てで 標識細胞を認めなかった。

3. 咽頭の結果

HRP を咽頭に投与した12例の結果を表 3 亿 示した。

a）上咽頭に HRP を注入した 4 例のうち 3

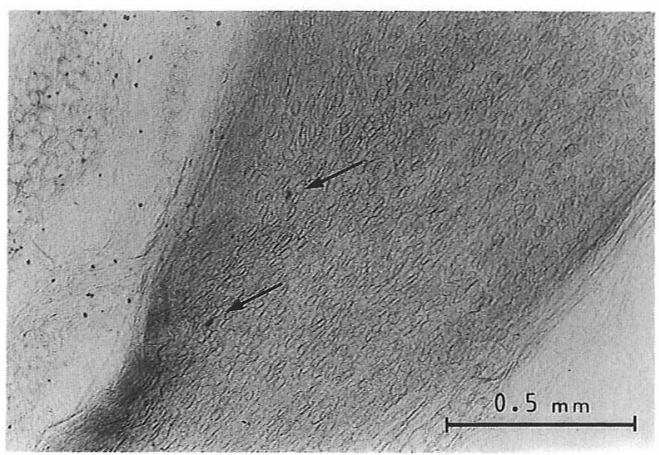

図 3 中頸神経節の HRP 標識細胞
例で同側の上頸神経節に標識細胞を認めた。し かし反対側には認めなかった。また中頸神経節 と星状神経節には全例標識細胞を認めなかった。 翼口蓋神経節には 4 例中 3 例で標識細胞を認め, うち 1 例 (cat no. 20) では両側性に認められた. 耳神経節は 2 例検索したが，いずれ屯標識細胞 を認めなかった，標識細胞数は上頸神経節が 2 〜12個，翼口蓋神経節が 4 21個であった． cat no. 20 の翼口蓋神経節は両側に各 4 個認めた.

b）中咽頭に HRP を注入した 4 例のうち 3 例で両側の上頸神経節に標識細胞を認めた。 こ の 3 例では同側の中頸神経節にも標識細胞を認 め，うち 2 例 (cat no. 23, 25) では同側の星状神

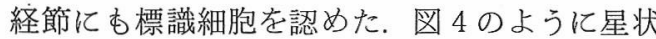
神経節の標識細胞は卵円形で，大きさは上頸神 経節の細胞とほぼ同様であった。翼口蓋神経節 には全例標識細胞を認めず，また耳神経節にあ 標識細胞を認めなかった。標識細胞数は上頸神 経節の同側が61〜 84個で反対側が2〜 5個，中頸 神経節，星状神経節は同側のみでそれぞれ 7 14個，1〜5個であった。

c）下咽頭に HRP を注入した 4 例のうち 3 例で両側の上頸神経節に HRP 標識細胞を認め た。 また 4 例全例で注入側の中頸神経節に標識 細胞を認め，うち1例 (cat no. 29) では反対側

表 2 耳管の結果

\begin{tabular}{|c|c|c|c|c|c|}
\hline cat no. & SCG & MCG & S t G & Pp G & O t G \\
\hline 9 & - & & - & - & \\
\hline 10 & - & - & - & & \\
\hline 11 & - & & - & - & - \\
\hline 12 & H & & - & + & \\
\hline 13 & H & + & - & - & - \\
\hline 14 & H & & - & + & \\
\hline 15 & + & - & - & - & - \\
\hline 16 & H & & - & + & - \\
\hline 17 & H & - & - & + & - \\
\hline 18 & H & & - & & - \\
\hline
\end{tabular}

cat no. 9〜11: HRP 綿球を耳管腔に留置した例 cat no. 12〜18: HRP を直接耳管粘膜に注入した例 
にも標識細胞を認めた。星状神経節には 3 例 で注入側に標識細胞を認め, うち 1 例 (cat no. 29）では反対側にも認めた。 翼口蓋神経節には 全例標識細胞を認めなかった，標識細胞数は上 頸神経節の同側が 31〜152 個で反対側が 3 5個, 中頸神経節の同側が $2 \sim 11$ 個で 反対側が 3 個, 星状神経節の同側が 2 18 個で反対側が 4 個で あった。

\section{考: 察}

1. 中耳の自律神経支配について

1950年 Rosen 1) は難聴や眩暈に対する鼓室神

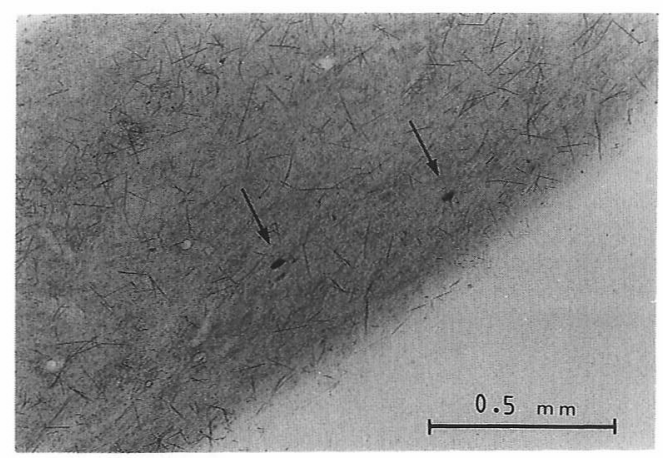

図4 星状神経節の HRP 標識細胞
経叢や鼓索神経の役割を，屍体標本を拡大鏡で 観察する古典的な方法で検討し，舌咽神経の枝 である Jacobson 神経が頸動脈神経叢からの交 感神経線維上鼓室内で吻合し，その分枝が卵円 㥶，正円㥶あるいは耳管にあ分布するととを報 告した。また Mitchell ${ }^{12)}$ (1954年) は中耳粘膜 が岬角上の鼓室神経叢により神経支配され，そ の鼓室神経叢は主に交感系が頸動脈神経叢から の分枝, 副交感系が Jacobson 神経により構成 されると述べている.

Ishii ら²（1976年）は組織化学的手法および 電子顕微鏡による観察で, 下鼓室動脈やその枝 にアドレナリン作㗢神経が分布しているとと， 耳管鼓室孔周辺粘膜にアセチルコリンエステラ 一ゼ活性のある神経叢が存在するととを観察し， さらに鼓室神経叢の小神経節にコリン作働神経 終末が認められるととも報告した。中耳粘膜内 に vasoactive intestinal peptide (VIP), substance $\mathrm{P}$ などの神経ペプチド含有線維が存在する ととも観察され ${ }^{3)}$ ，また螢光組織化学的方法で アドレナリン作働神経の中耳腔内分布様式を検 索した報告あある( $)$.

表 3 咽頭の結果

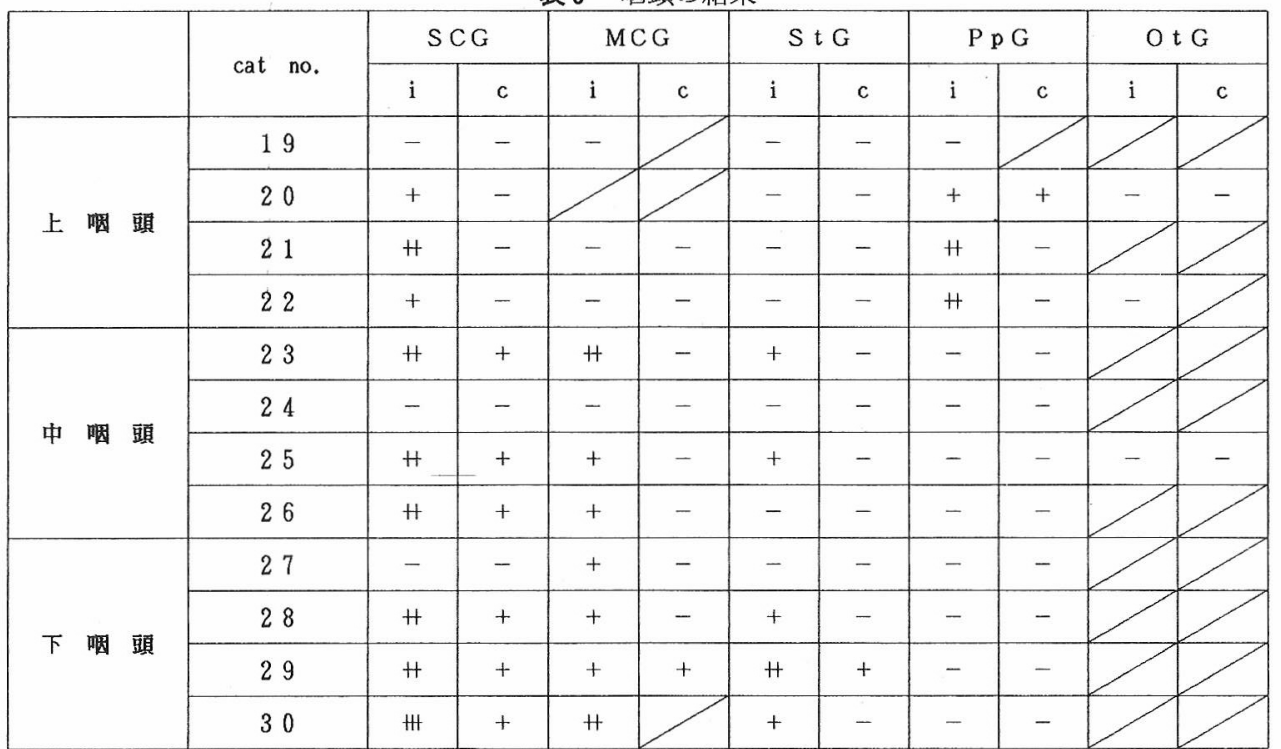

i : HRP 注入側と同側

c : HRP 注入側と反対側 
以上のような研究により中耳が自律神経支配 を受けることが確かめられてきたが，中耳粘膜 に直接分布している自律神経節後線維が，よ゙の 自律神経節を起源としているかについてはなお 明らかではなかった。

今回の実験で HRP の中耳粘膜注入により, 全例で注入側の上頸神経節に HRP 標識細胞を 認めた。乙れは上頸神経節に細胞体を持つ節後 線維が同側の中耳粘膜に到達しており, その神 経終末から取り込まれた HRP が軸索を逆行性 に輸送され，上頸神経節の細胞体に集積したも のと考えられた．また反対側の上頸神経節に全 く標識細胞を認めなかったととは, 中耳粘膜の 交感支配が一側性であるととを示すむのと考え られた。

中頸神経節，星状神経節にはいずれの例でも 標識細胞を認めず，中頸神経節，星状神経節か らの節後線維は中耳粘膜に分布していないと考 えられた。

翼口蓋神経節を検索した 5 例のうち 4 例で HRP 注入側に標識細胞を認めた。一般的に翼 口蓋神経節に細胞体を有する神経は副交感神経 節後線維とみなされており，中耳粘膜が同側の 翼口蓋神経節に起源をむつ節後線維で副交感支 配されていると考えられた。

耳神経節には全く標識細胞を認めなかった。 耳神経節は副交感神経節後線維を耳下腺に送っ ているが20)，中耳腔にはその支配が及んでいな いと考えられた。

以上のように本研究により中耳粘膜が同側の 上頸神経節, 翼口蓋神経節からの節後線維で, それぞれ交感，副交感支配を受けているととが 明らかにされた。しかし翼口蓋神経節の標識細 胞数が上頸神経節に較べ著しく少ないととから， 中耳には翼口蓋神経節のほか毛様体神経節や顎 下神経節，さらには別経路からの副交感支配が 及んでいる可能性もあるものと考えられた。

自律神経の中耳に及咕す作用については不明 な点屯多いが，恐らく粘膜の血流や粘液の産生 あるいは線毛機能に影響を与えている屯のと考
えられる. 最近の動物実験で, 外耳道刺激で認 められた中耳滲出液が，迷走神経切断例では認 められない211 との報告ああり，実験的にも臨床 的にあ今後さらに究明されるべき課題と思わ れた。

\section{2. 耳管の自律神経支配について}

中耳腔の換気や排泄は耳管を介して行なわれ， 中耳病態は耳管機能と密接に関連している ${ }^{22)}$. 耳管は主に燕下時の口蓋帆張筋の収縮で開大す $る^{23)}$ が，耳管機能は耳管粘膜の線毛運動や自律 神経などにも影響されることが知られている。

Ingelstedt ら ${ }^{6)}$ （1963年）は血管収縮剂を耳 管腔に吹きつけると耳管の開放度が増すととを 報告し, Sheffield ら7) (1970年) はノルエピネ フリン，イソプロテレノールの頸動脈からの投 与によりそれぞれ耳管が開放，閉塞傾向を示す ことを観察した。ささらに頸部父感神経の電気刺 激で耳管の開放度が増し ${ }^{8)}$ ，Vidian 神経の刺 激で逆に開放度が減少する ${ }^{24)}$ とも明らかにさ れたが，乙れは耳管粘膜に分布する血管の収縮 や拡張による作用と考えられた，最近では組織 化学的手法 ${ }^{92}$ 11) や電子顕微鏡での観察 ${ }^{25}$ によ り，耳管粘膜にアドレナリン作働神経，アセチ ルコリンエステラーゼ活性陽性神経, VIP 神経 などが分布していることも確かめられている.

本実験に㧍いて，HRP 溶液を耳管粘膜に注 入した例では上頸神経節に多数の標識細胞を認 め，そのうちの1例では中頸神経節にも標識細 胞を認めたととにより，耳管が主に上頸神経節 からの節後線維で交感支配を受け，さらに中頸 神経節からも一部交感支配を受けていることが 示唆された. Kumazawa ${ }^{26)}$ は星状神経節ブロッ クを受けた患者の耳管が閉塞傾向を示すととを 報告しているが，乙れは主に星状神経節を通過 し上頸神経節に終る節前線維をブロックするこ とによる効果と考えられる.

また翼口蓋神経節にも標識細胞が認められ， 耳管粘膜にも中耳と同じく翼口蓋神経節から一 側性の副交感支配が及ぶことが示された。 三叉 神経痛の治療として，翼口蓋神経節ブロックを 
受けた患者の耳管が開放傾向を示す26) ことも報 告されているが，乙れは今回の結果に一致する あのと思われた。

耳神経節には全く標識細胞が認められず，中 耳之同じく耳管にも耳神経節からの副交感支配 はないと考えられた。

HRP 溶液を耳管腔内に貯留させた例では標 識細胞が全く認められず，乙れはアドレナリン 作働神経やコリン作働神経が粘膜下層や小血 管, 分泌腺周囲に分布するととを観察したUdd$\operatorname{man}^{92}$ や Kitajiri ${ }^{25)}$ の報告と符合する.

今回の実験において中耳と耳管の結果で異な る点は，耳管には中頸神経節からも一部交感支 配が及んでいる可能性のあるととだけであった。 これは耳管が中耳より尾側に位置することに基 づくあのと思われた。

3. 咽頭の自律神経支配について

Mitchell ${ }^{12)}$ は咽頭む他の消化管と同様，交感 神経と副交感神経とが吻合してできた神経叢を 介し支配され，交感系は上頸神経節からの分枝 や上行咽頭動脈, 口蓋動脈に随伴してさた外頸 動脈神経叢からの枝により, また副交感系は舌 咽神経や迷走神経の分枝によりもたらされると 報告している。しかし咽頭を上咽頭，中咽頭， 下咽頭と三領域に分けた場合，それぞれの自律 神経支配様式にどのような差異があるのか，ま だ明らかにされていない。

本実験において HRP を上咽頭に投与した例 では上頸神経節と翼口蓋神経節だけに標識細胞 を認めたが，乙れは上咽頭に上頸神経節，翼口 蓋神経節からの節後線維は分布しているが, 中 頸神経節, 星状神経節, 耳神経節汃らの節後線 維は分布していないととを示している．上頸神 経節による交感支配は中耳や耳管と同様一側性 支配であったが，翼口蓋神経節による副交感支 配は両側支配もあり得ることが示唆された.

また表 3 で示したように，上咽頭の自律神経 支配様式は中咽頭, 下咽頭のそれとは際立った 違いをみせており，むしろ中耳や耳管に近いも のであった．鼻粘膜に上頸神経節や翼口蓋神経
節からの節後線維が分布していることは既に明

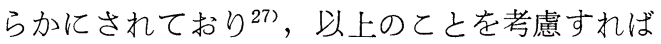
互いに隣接した器官である中耳, 耳管, 上咽頭, 鼻腔がほぼ同様の自律神経支配を受けているあ のと考えられた。

今回の実験結果によれば中咽頭と下咽頭の自 律神経支配様式は互いに類似していた. 即ち両 者とも交感系は上頸神経節，中頸神経節，星状 神経節いずれの神経節からも節後線維が到達し ているが，副交感系の翼口蓋神経節からの支配 は認められなかった。耳神経節については上咽 頭，中咽頭の例で標識細胞を認めておらず，ま た耳神経節の解剖学的な位置関係も考慮すれば, 咽頭に耳神経節からの節後線維は分布していな いと考えられた。 また中咽頭，下咽頭の例では 両側の上頸神経節に標識細胞が認められ, 交感 神経の両側性支配は中咽頭，下咽頭の特徵之思 われた。 しかし上頸神経節の標識細胞数は圧倒 的に注入側に多く，同側優位の両側性支配と考 えられた。

中咽頭と下咽頭とを比較すれば，下咽頭では 中咽頭よりも中頸神経節と星状神経節に標識細 胞を認めることが多くなり, 下咽頭では中頸神 経節や星状神経節由来の節後線維で交感支配さ れる割合がより增大するととを示すものと考え られた。

中咽頭と下咽頭の副交感支配に関しては, 翼 口蓋神経節や耳神経節からの節後線維が分布し ていないととのほか新知見を得るととはできな かった。一般に咽頭は迷走神経と舌咽神経によ って副交感支配されると言われているが，乙れ らの神経にはそれぞれ延䯣の迷走神経背側核と 下唾液核から起とる節前線維が含まれている 従って咽頭の分泌腺などで副交感神経として機 能するためには，どてかの神経節で節後線維に 連絡するものと思われる. 今回検索し得なかっ た顎下神経節などで節後線維に連絡している可 能性むあるが，食道や胃が食道壁，胃壁にある 神経叢の小神経節から起こる節後線維で副交感

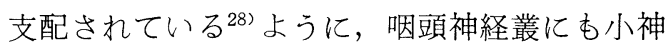


経節が存在し，そこからの節後線維で副交感支 配されている可能性むあると考えられた.

本研究により中耳, 耳管, 咽頭粘膜の自律神 経支配につき幾つかの知見を得ることができた が, 今回の実験では顎下神経節や舌咽, 迷走神 経節は対象とされておらず，今後検討されるべ き課題と思われる。

\section{結語}

HRP で自律神経節を標識することにより中 耳, 耳管, 咽頭粘膜の自律神経支配につき検索 し，以下の結果を得た。

1. 中耳粘膜は同側の上頸神経節からの節後 線維で交感支配されるが, 中頸神経節や星状神 経節からの節後線維は分布していない。 また同 側の翼口蓋神経節からの節後線維で副交感支配 されるが，耳神経節からの節後線維は分布して いない。

2. 耳管粘膜は中耳粘膜と同じく主に同側の 上頸神経節からの節後線維で交感支配され，さ らに中頸神経節からの節後線維による支配も示 唆された。 また同側の翼口蓋神経節からの節後 線維で副交感支配される。

3.上咽頭は同側の上頸神経節からの節後線 維で交感支配され, 中頸神経節や星状神経節か らの節後線維は分布していない。 また翼口蓋神 経節からの節後線維で副交感支配されるが，耳 神経節からの節後線維は分布していない.

4. 中咽頭と下咽頭には上頸神経節, 中頸神 経節, 星状神経節いずれの神経節からも節後線 維が分布して扣り，交感支配は同側優位の両側 性支配であった。しかし翼口蓋神経節や耳神経 節からの節後線維は分布していなかった。

稿を終るに臨み, 本研究の御指導掞よび本論文の御 校閲を賜りました京都大学医学部耳鼻咽喉科学教室教 授, 本庄 嚴先生に深く感謝致します. また終始実験 を御指導下さいました京都大学医学部耳鼻咽喉科学教 室講師，伊藤壽一先生，ならびに本論文作成にあたり 御助言をいただきました天理よろづ相談所病院耳鼻咽 喉科部長, 北村溥之先生に厚く御礼申し上げます.

本論文の要旨は昭和61年10月第31回日本オージオロ
ジー学会総会, 昭和 62 年 2 月第36回日耳鼻京滋合同地 方部会, 昭和 62 年 9 月第 222 回日耳鼻大阪地方連合会, 昭和 63 年 11 月第 40 回日本気管食道科学会総会で発表 した.

なお本研究の一部は文部省科学研究費によって行な われた。

\section{参考文献}

1) Rosen $\mathrm{S}:$ The tympanic plexus. Arch Otolaryngol $52: 15 \sim 18,1950$.

2) Ishii $T$ and Kaga $\mathrm{K}:$ Autonomic nervous system of the cat middle ear mucosa. Ann Otol 85 Suppl $25:$ 51 57, 1976.

3) Uddman R, Kitajiri $M$ and Sundler F : Autonomic innervation of the middle ear. Ann Otol $92: 151 \sim 154,1983$.

4 ）山下敏夫, 北尻雅則, 熊澤忠躬 : 中耳粘膜の交感 神経分布. 耳鼻臨床 $76: 95 \sim 98,1983$.

5 ) Uddman R, Sundler F and Emson P : Occurrence and distribution of neuropeptide-Yimmunoreactive nerves in the respiratory tract and middle ear. Cell Tissue Res $237: 321 \sim 327$, 1984.

6) Ingelstedt $S$, Ortegren U, Flisberg K, et al : On the function of middle ear and Eustachian tube. Acta Otolaryngol (Stockh) Suppl $182: 1 \sim 93$, 1963.

7 ) Sheffield PA, Jackson RT and Davis LJ : Patency changes in dog's Eustachian tube in response to alpha and beta adrenergic drugs. Ann Otol $79:$ 117 123, 1970.

8) Jackson RT : Pharmacological mechanisms in the Eustachian tube. Ann Otol $80: 313 \sim 318$, 1971.

9) Uddman R, Alumets J, Densert O, et al : Innervation of the feline Eustachian tube. Ann Otol 88 : 557 561, 1979.

10) Yamashita T, Amano H, Kumazawa $T$, et al : Adrenergic innervation in the Eustachian tube of guinea pigs. Arch Otorhinolaryngol $225: 279 \sim$ 282, 1979.

11）山下敏夫, 北尻雅則, 友田幸一, 他: 耳管におけ る副交感神経分布. 耳鼻臨床 $74: 873 \sim 879$, 1981. 
12) Mitchell GAG : The autonomic nerve supply of the throat, nose and ear. J Laryng Otol 68 : 495 516, 1954.

13）鈴木安恒：耳鼻咽喉科領域におけるレーリ一氏現 象. 日耳鼻 $66: 1473 \sim 1493,1965$.

14) Kristensson $K$ and Olsson $Y$ : Retrograde axonal transport of protein. Brain Res $29: 363 \sim 365$, 1971.

15) Mesulam MM : Tetramethyl benzidine for horseradish peroxidase neurohistochemistry; a noncarcinogenic blue reaction-product with superior sensitivity for visualizing neural afferents and efferents. J Histochem Cytochem $26: 106 \sim$ 117, 1978.

16）伊藤和夫：HRP の順行性, 逆行性標識. 生命の 科学 $36: 360 \sim 362,1985$.

17) Ito J, Markham $\mathrm{CH}$ and Curthoys IS : Projections to eye movement-related pause neuron region in cat using HRP. Exp Neurol $86: 93 \sim$ 104, 1984.

18）光増高夫：ネコの疑核に投射する神経細胞に関す る研究. 耳鼻 $30: 1106 \sim 1134,1984$.

19) Oyagi S, Ito $J$ and Honjo I : Topographic study of the feline trigeminal ganglion via the horseradish peroxidase tracer method. Brain Res $476: 382 \sim 383,1989$.

20) 平沢 興, 岡本道雄: 解剖学 2 . 脈管学・神経系. 378頁, 385 393頁, 金原出版, 東京, 1969.

21) Goldie $\mathrm{P}$ and Hellstrom $\mathrm{S}$ : Autonomic nerves and middle ear fluid production. Acta Otolaryn- gol (Stockh) $106: 10 \sim 18,1988$.

22) 本庄 䉷:耳管と中耳病態. 第 88 回日耳鼻総会 宿題報告モノグラフ，1987.

23) Honjo I, Okazaki $\mathrm{N}$ and Kumazawa $\mathrm{T}$ : Experimental study of the Eustachian tube function with regard to its related muscles. Acta Otolaryngol (Stockh) $87:$ 84 89, 1979.

24) Nathanson SE and Jackson RT : Vidian nerve and the Eustachian tube. Ann Otol $85: 83$ 85, 1976.

25) Kitajiri M, Yamashita T, Shinomiya M, et al : Electron-microscopic observation of adrenergic innervation in guinea pig Eustachian tube. Arch Otorhinolaryngol $228:$ 123 126, 1980.

26) Kumazawa $\mathrm{T}$ : Autonomic nerve regulation in the Eustachian tube function. Auris Nasus Larynx (Tokyo) 12 Suppl 1:5〜7, 1985.

27) Azuma E, Asakura K and Kataura A : Histochemical demonstration of peripheral autonomic innervation in canine nasal mucosa by retrograde axonal transport of horseradish peroxidase. Acta Otolaryngol (Stockh) $93:$ 139 146, 1982.

28) Netter FH: The Ciba collection of medical illustrations vol. 1 Nervous system. pp 93, Ciba Co, New York, 1953.

$\left(\begin{array}{l}\text { 原稿受付 : 平成元年 } 6 \text { 月 } 19 \text { 日 } \\ \text { 原稿採択 : 平成元年 } 8 \text { 月 } 1 \text { 日 } \\ \text { 別刷請求先 : 大八木章博 } \\ \text { † } 632 \text { 天理市三島町 } 200 \\ \text { 天理よろづ相談所病院耳鼻咽喉科 }\end{array}\right)$

